\title{
Tingkat Manajemen Risiko Bencana Tsunami Berbasis Masyarakat di RW. 08 Kelurahan Ploso Kabupaten Pacitan
}

\author{
Rachman Adhi Nugroho dan Adjie Pamungkas \\ Jurusan Perencanaan Wilayah dan Kota, Fakultas Teknik Sipil dan Perencanaan, \\ Institut Teknologi Sepuluh Nopember (ITS) \\ Jl. Arief Rahman Hakim, Surabaya 60111 Indonesia \\ e-mail: adjie.difi@gmail.com
}

\begin{abstract}
Abstrak-Kabupaten Pacitan merupakan wilayah yang berpotensi terdampak bencana tsunami. Adanya kawasan pantai dengan karakteristik bentuk teluk menyebabkan semakin meningkatnya risiko bencana tsunami jika terjadi di lingkungan yang berbatasan langsung dengan pantai tersebut. Berdasarkan penelitian yang pernah dilakukan, tingkat ketahanan masyarakat pesisir Pacitan masih rendah. Namun, pada akhir tahun 2015 dibentuk kelompok sadar keselamatan pantai di lingkungan RW.08 Kelurahan Ploso Kabupaten Pacitan yang ditujukan agar dapat menanggulangi bencana laut dan menjaga keselamatan pengunjung. Oleh karena itu, dibutuhkan kajian dalam menganalisa tingkat manajemen risiko bencana tsunami berbasis masyarakat di RW. 08 Kelurahan Ploso Kabupaten Pacitan, sebagai bahan dalam perumusan konsep manajemen risiko bencana tsunami berbasis masyarakat kedepannya. Artikel ini merupakan bagian dari penelitian mengenai konsep manajemen risiko bencana tsunami berbasis masyarakat (studi kasus: RW. 08 Kelurahan Ploso Kabupaten Pacitan). Melalui teknik analisis isi (content analysis) dapat diketahui tindakan-tindakan manajemen risiko bencana tsunami yang telah dilakukan oleh masyarakat di RW. 08 Kelurahan Ploso Kabupaten Pacitan. Hasil penelitian ini menunjukkan bahwa tingkat manajemen risiko bencana tsunami berbasis masyarakat sudah sangat bagus dengan persentase ratarata $89,34 \%$ tahapan manajemen sudah pernah dilakukan oleh masyarakat.
\end{abstract}

Kata Kunci-Tsunami, Pacitan, Manajemen Risiko, Content Analysis.

\section{PENDAHULUAN}

$\mathrm{T}$ SUNAMI merupakan serangkaian gelombang laut yang terjadi secara tiba-tiba, yang disebabkan oleh adanya pergerakan atau perpindahan air dalam jumlah sangat banyak akibat gempa bumi, longsoran, erupsi gunung berapi dan meteor yang terjadi di lautan [1]. Kondisi geografis Indonesia berada pada zona tektonik aktif yang memiliki kerentanan tinggi terhadap gempa bumi dan tsunami [2]. Kabupaten Pacitan memiliki kerawanan yang tinggi terhadap bencana tsunami khususnya pada kawasan Teluk Pacitan [3].

Dalam Kajian Risiko Bencana Kabupaten Pacitan, Kelurahan Ploso termasuk kawasan yang memiliki tingkat kelas bahaya tsunami tinggi dengan wilayah paling selatan berbatasan langsung dengan bibir pantai adalah RW.08 [4]. Sebagai bentuk penanggulangan bencana, partisipasi masyarakat lebih menjadi titik berat untuk mengurangi risiko bencana dengan meningkatkan kapasitas masyarakat. Pelibatan aktif masyarakat dalam mengurangi risiko bencana melalui identifikasi, analisis, penanganan, pemantauan dan evaluasi merupakan tindakan manajemen risiko bencana berbasis masyarakat.

Dari studi yang pernah dilakukan, ketahanan masyarakat pesisir Pacitan terhadap bencana tsunami masih rendah, khususnya dalam pengetahuan tentang risiko, peringatan dan evakuasi, serta respon terhadap keadaan darurat [5]. Tetapi, di lingkungan RW.08 Kelurahan Ploso Kabupaten Pacitan sudah mulai membentuk kelompok sadar keselamatan untuk menyiapkan masyarakat dalam menanggulangi bencana [6].

Oleh karena itu, perlu diketahui tingkat manajemen risiko bencana tsunami berbasis masyarakat di lingkungan RW.08 Kelurahan Ploso Kabupaten Pacitan sebagai landasan perumusan konsep manajemen risiko bencana tsunami berbasis masyarakat yang nantinya dapat diterapkan untuk mengurangi risiko dan meningkatkan ketahanan masyarakat terhadap bencana tsunami.

\section{METODE PENELITIAN}

\section{A. Metode Pengumpulan Data}

Pada penelitian ini, metode pengumpulan data yang digunakan adalah teknik survei primer dan sekunder. Survei primer melalui wawancara semi terstruktur kepada stakeholders terpilih yang terdiri dari kelompok pemerintahan (Badan Perencanaan Pembangunan Daerah Kabupaten Pacitan (G1), Badan Penanggulangan Bencana Daerah Kabupaten Pacitan (G2), Dinas Kelautan dan Perikanan Kabupaten Pacitan (G3), Dinas Sosial Tenaga Kerja dan Transmigrasi Kabupaten Pacitan (G4)), kelompok masyarakat (Taruna Siaga Bencana) (C1 dan C2), Perangkat RW. 08 Kelurahan Ploso (C3), Kelompok Masyarakat Sadar Keselamatan RW. 08 Kelurahan Ploso (C4)), dan kelompok swasta (Pihak Swasta Kelurahan Ploso (PS1)). Sedangkan survei sekunder dilakukan dengan survei instansional untuk memperoleh gambaran umum wilayah dan gambaran kelompok masyarakat sadar keselamatan di RW. 08 Kelurahan Ploso Kabupaten Pacitan.

\section{B. Metode Analisis}

Untuk menganalisis tingkat manajemen risiko bencana 
tsunami di RW. 08 Kelurahan Ploso Kabupaten Pacitan digunakan teknik analisa isi (content analysis) yaitu, suatu teknik analisis yang mengeksplorasi kode-kode yang ditemukan dalam teks perekaman data [7]. Unit analisis yang digunakan sebagai bahan ekspolorasi adalah unit kalimat dalam teks perekaman. Proses content analysis dalam penelitian ini adalah melakukan kajian pustaka terkait tingkat manajemen risiko bencana tsunami berbasis masyarakat terlebih dahulu, dimana menghasilkan variabel tindakan manajemen yang menjadi parameter dalam eksplorasi data dan informasi kepada stakeholder terpilih.

Hasil dari eksplorasi tersebut dikonversi menjadi transkrip wawancara yang akan menjadi data teks untuk pengkodean. Proses pengkodean yang digunakan adalah semantical content analysis, dimana akan mengklasifikasikan tanda-tanda berdasarkan makna yang dimiliki, selanjutnya disederhanakan dalam tabulasi menggunakan assertion analysis untuk menunjukkan frekuensi mengenai indikasi akan tindakan manajemen risiko bencana tsunami berbasis masyarakat yang dilakukan atau tidak dilakukan oleh masyarakat di lingkungan RW.08 Kelurahan Ploso Kabupaten Pacitan. Selanjutnya, melihat kembali elemen percakapan berupa gaya bicara pada hasil pengkodean untuk melihat penekanan dan validitas tindakan manajemen yang dilakukan oleh masyarakat. hasil akhir dari proses analisa ini adalah megetahui bentuk tindakan manajemen pada setiap tingkat manajemen.

Unitizing $\left.\left.\left.\left.\left.\rangle \begin{array}{c}\text { Sampl } \\ \text { ing }\end{array}\right\rangle \begin{array}{l}\text { ding } \\ \text { Codin }\end{array}\right\rangle \begin{array}{c}\text { Reduc } \\ \text { ing }\end{array}\right\rangle \begin{array}{c}\text { inferr } \\ \text { ing }\end{array}\right\rangle \begin{array}{l}\text { Narra } \\ \text { ting }\end{array}\right\rangle$

Gambar 1. Tahap Content Analysis [9]

\section{HASIL DAN PEMBAHASAN}

\section{A. Hasil Pengkodean dan Validasi Data}

Hasil dari pengkodean didasarkan pada traskrip wawancara 9 stakeholder yang telah dilakukan terlebih dahulu melalui indepth interview. Tahapan pengkodean bertujuan untuk menemukan kode yang mengindikasi tindakan manajemen pengurangan risiko bencana tsunami berbasis masyarakat di RW. 08 Kelurahan Ploso Kabupaten Pacitan. Berikut contoh penemuan kode dalam transkrip wawancara.

PO1.15 C 4 : bentuknva membentuk kelompok, itu kelompok penanganan sadar bencana. Jadi masvarakat sini sudah membentuk kelompok sadar bencana, misalkan teriadi bencana itu masyarakat sini ada kelompok masvarakat vang menanggulangi bencana itu. Artinva mengadakan, masvarakat sini membentuk kelompok dengan sadar disitu untuk penanganan bencana, baik itu tsunami atau bencanabencana vang lain.

Gambar 2. Kutipan Temuan Kode pada Stakeholder 8 (C4)

Berdasarkan kutipan di atas, menurut stakeholder 8 (C4), yang mengindikasikan tindakan pembentukan organisasi masyarakat (PO1) dilakukan oleh masyarakat yaitu dengan membentuk kelompok sadar bencana (PO1.15 dan PO1.16) dan adanya pembentukan kelompok masyarakat tersebut adalah untuk penanganan bencana, baik tsunami maupun bencanabencana yang lain. Indikasi tersebut dapat disimpulkan bahwa stakeholder 8 menanggap masyarakat telah melakukan pembentukan organisasi masyarakat di RW.08 Kelurahan Ploso dalam bentuk kelompok sadar bencana. proses pengkodean dimana dititik beratkan terhdap makna unit analisa berlaku untuk mengindikasikan tindakan manajemen, jumlah unit analisa yang berulang dengan makna yang sama dapat mendukung penyimpulan indikasi dari suatu pengaruh variabel tindakan manajemen risiko bencana tsunami di RW. 08 Kelurahan Ploso Kabupaten Pacitan.

Berdasarkan keseluruhan hasil pengodean tersebut, pernyataan dari masing-masing stakeholders tidak selalu mengindikasi jawaban yang sama dalam satu variabel tindakan manajemen yang sama. Stakeholder yang memberikan pernyataan belum pernah adanya tindakan manajemen dari setiap variabel yang ditanyakan kecenderungan kurang mengetahui perkembangan yang ada pada lingkungan masyarakat RW. 08 Kelurahan Ploso. Sedangkan Stakeholder yang memberikan pernyataan sudah pernah andanya tindakan manajemen pada setiap variabel, menunjukkan bentuk tindakan yang telah dilakukan oleh masyarakat RW. 08 Kelurahan Ploso Kabupaten Pacitan.

Tabel 1.

Frekuensi Pernyataan Stakeholders tiap Variabel Tindakan Manajemen

\begin{tabular}{|c|c|c|}
\hline \multirow{2}{*}{$\begin{array}{l}\text { Variabel Tindakan } \\
\text { Manajemen }\end{array}$} & \multicolumn{2}{|c|}{ Jumlah Stakeholders } \\
\hline & $\begin{array}{c}\text { Mengindikasi } \\
\text { Melakukan Tindakan }\end{array}$ & $\begin{array}{l}\text { Mengindikasi Tidak } \\
\text { Melakukan Tindakan }\end{array}$ \\
\hline $\begin{array}{l}\text { Pengamatan tindakan } \\
\text { individu }\end{array}$ & 4 & 4 \\
\hline $\begin{array}{l}\text { Pengembangan } \\
\text { ketrampilan individu }\end{array}$ & 5 & 4 \\
\hline $\begin{array}{l}\text { Inisiatif tindakan } \\
\text { pengurangan risiko } \\
\text { bencana }\end{array}$ & 5 & 3 \\
\hline $\begin{array}{l}\text { Kerjasama antar } \\
\text { individu }\end{array}$ & 7 & 0 \\
\hline $\begin{array}{l}\text { Evaluasi tindakan } \\
\text { individu }\end{array}$ & 5 & 3 \\
\hline $\begin{array}{l}\text { Identifikasi kelompok } \\
\text { masyarakat }\end{array}$ & 5 & 2 \\
\hline $\begin{array}{l}\text { Pembentukan dan } \\
\text { pemahaman hubungan } \\
\text { sosial masyarakat }\end{array}$ & 7 & 1 \\
\hline $\begin{array}{l}\text { Penilaian risiko } \\
\text { bencana secara } \\
\text { partisipatif }\end{array}$ & 5 & 2 \\
\hline $\begin{array}{l}\text { Perencanaan } \\
\text { pengurangan risiko } \\
\text { bencana }\end{array}$ & 8 & 1 \\
\hline $\begin{array}{l}\text { Pembentukan organisasi } \\
\text { masyarakat }\end{array}$ & 4 & 3 \\
\hline $\begin{array}{l}\text { Perekrutan dan } \\
\text { pengembangan anggota }\end{array}$ & 5 & 2 \\
\hline kelompok masyarakat & & \\
\hline $\begin{array}{l}\text { Pembagian tugas dan } \\
\text { kerja }\end{array}$ & 6 & 1 \\
\hline $\begin{array}{l}\text { Kerjasama dengan } \\
\text { pihak lain }\end{array}$ & 6 & 1 \\
\hline $\begin{array}{l}\text { Pembuatan sistem } \\
\text { peringatan dini }\end{array}$ & 7 & 1 \\
\hline $\begin{array}{l}\text { Penyebaran informasi } \\
\text { ke masyarakat }\end{array}$ & 7 & 2 \\
\hline $\begin{array}{l}\text { Peningkatan } \\
\text { pengetahuan }\end{array}$ & 4 & 2 \\
\hline
\end{tabular}


Penggunaan media

dalam penyampaian

informasi

Pembuatan pusat

informasi

Pemantauan informasi

Pelaporan informasi

Evaluasi partisipasi

Sumber: Hasil Analisis, 2016

Berdasarkan tabel diatas, dapat dilihat bahwa terjadi kecenderungan bahwa dari keseluruhan pernyataan stakeholder secara dominan lebih banyak yang menyatakan bahwa masyarakat telah melakukan tindakan manajemen risiko bencana tsunami berbasis masyarakat.

\section{B. Hasil Pemahaman Data}

Pada tahapan selanjutnya, hasil dari pengodean dan validasi data yang telah dilakukan di atas, akan kembali dieksplorasi dengan melihat elemen percakapan berupa gaya bicara seperti intonasi, mimik, dan lain sebagainya. Sehingga dapat diketahui signifikansi suatu variabel tindakan manajemen risiko bencana tsunami yang telah dilakukan oleh masyarakt di RW. 08 Kelurahan Ploso Kabupaten Pacitan. Terdapat beberapa bentuk gaya bicara ketika stakeholder terpilih memberikan pernyataan terhadap cariabel yang ditanyakan, yaitu adanya penekanan, sangat yakin, datar, dan ragu-ragu. Berikut merupakan contoh kutipan dalam transkrip wawancara terkait elemen percakapan.

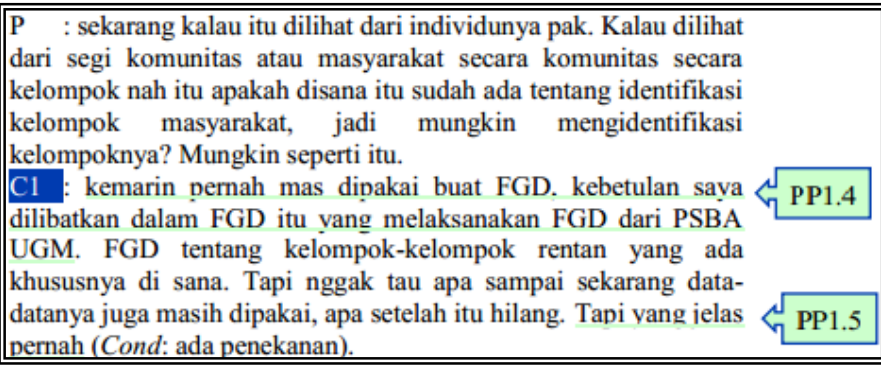

Gambar 3. Kutipan Temuan Kode pada Stakeholder 5 (C1)

Berdasarkan kutipan transkrip diatas, diketahui bahwa stakeholder 5 (C1) dalam menyatakan indikasi tindakan identifikasi kelompok masyarakat terjadi penekanan sehingga menunjukkan adanya peningkatan intonasi dari kondisi normal. Hal tersebut merepresentasikan bahwa masyarakat di RW. 08 Kelurahan Ploso Kabupaten Pacitan pernah melakukan tindakan manajemen risiko berupa identifikasi kelompok masyarakat yaitu dalam bentuk identifikasi kelompokkelompok rentan.

\section{Penarasian (Abstraksi Hasil)}

Selanjutnya pada tahapan penarasian hasil pemahaman data yang telah diubah menjadi bentuk-bentuk tindakan manajemen risiko bencana tsunami yang sudah pernah dilakukan masyarakat di RW.08 Kelurahan Ploso Kabupaten Pacitan. Selain itu, variabel-variabel tindakan manajemen risiko tersebut di masukkan kedalam tingkat manajemen risiko bencana berbasis masyarakat. Berikut ini merupakan variabel-variabel tindakan manajemen risiko bencana berbasis masyarakat yang dilakukan di RW. 08 Kelurahan Ploso Kabupaten Pacitan sesuai dengan tingkat manajemen.
1) Manajemen Diri

Tabel 2.

Presentase Tahap Manajemen Diri

\begin{tabular}{ccc}
\hline \hline Tahapan Manajemen & \multicolumn{1}{c}{ Tindakan Manajemen } & Persentase \\
\hline & $\varpi$ Pengamatan tindakan & \\
& individu & \\
& $\varpi$ Pengembangan keterampilan & \\
Manajemen diri & individu & $100 \%$ \\
& $\varpi$ Inisiatif tindakan individu & \\
& $\varpi$ Kerjasama antar individu & \\
& $\varpi$ Evaluasi tindakan individu & \\
\hline & Sumber: Hasil Analisis, 2016
\end{tabular}

Pada tahap manajemen diri, masyarakat telah melakukan seluruh tindakan manajemen. Bentuk pengamatan tindakan individu yang dilakukan antara lain adalah mengamati sikap yang dilakukan dalam menanggapi bencana, mengamati tindakan pengelolaan sumberdaya dan lingkungan, dan mengamati tindakan pengurangan risiko bencana seperti fungsi dan manfaat menanam pohon cemara laut. Bentuk pengembangan ketrampilan individu yang dilakukan antara lain merawat pohon cemara laut, mengembangkan tindakan penyelamatan diri, mengembangkan keterampilan dalam memetakan diri, serta mengembangkan pemanfaatan teknologi seperti gadget. Selanjutnya bentuk inisiatif tindakan individu yang dilakukan antara lain memanfaatkan media sosial berupa whatsapp dan facebook untuk mendapatkan informasi, kemauan menjaga dan melestarikan cemara laut, mempersiapkan diri sendiri beserta keluarga jika sewaktu-waktu terdapat ancaman, serta segera merespon jika terdapat tanda-tanda bahaya. Bentuk kerjasama antar individu yang dilakukan antara lain gotong royong dan kerja bakti, pemanfaatan alat trasportasi mobil untuk evakuasi berkelompok. Bentuk Evaluasi tindakan individu yang dilakukan adalah evaluasi terhadap tindakan penanggulangan bencana berdasarkan pengalaman dan tindakan yang pernah dilakukan serta juga dari simulasi penanggulangan bencana yang pernah di ikuti, evaluasi perilaku yang tidak mendukung mitigasi, dan evaluasi tindakan yang dilakukan dalam lingkungan pesisir.

\section{2) Perencanaan dan Pengambilan Keputusan}

Tabel 3.

Persentase Tahap Perencanaan dan Pengambilan Keputusan

\begin{tabular}{|c|c|c|}
\hline $\begin{array}{c}\text { Tahapan } \\
\text { Manajemen }\end{array}$ & Tindakan Manajemen & Persentase \\
\hline $\begin{array}{l}\text { Perencanaan } \\
\text { dan } \\
\text { Pengambilan } \\
\text { Keputusan }\end{array}$ & $\begin{array}{l}\nabla \text { Identifikasi kelompok } \\
\text { masyarakat } \\
\square \text { Pembentukan dan } \\
\text { pemahaman hubungan sosial } \\
\square \text { Penilaian risiko bencana } \\
\text { secara partisipatif } \\
\square \text { Perencanaan pengurangan } \\
\text { risiko bencana }\end{array}$ & $100 \%$ \\
\hline
\end{tabular}

Pada tahap perencanaan dan pengambilan keputusan, masyarakat telah melakukan seluruh tindakan manajemen. Bentuk identifikasi kelompok masyarakat yang pernah dilakukan antara lain menyusun gambaran kelompok rentan setiap RT, melakukan penilaian kinerja, identifikasi kondisi ekonomi masyarakat, serta melakukan pemetaan kerentanan masyarakat. 
Identifikasi kelompok masyarakat juga dapat dilakukan sebagai penilaian kerentanan, dimana penilaian ini difokuskan untuk memprediksi dan memahami serta untuk mengurangi kerentanan yang akan datang. Sehingga kerentanan dapat dipahami dan masyarakat dapat mengubahnya sebagai kapasitas komunitas dalam mengatasi kejadian bencana [8]. Bentuk tindakan pembentukan dan pemahaman hubungan sosial yang dilakukan adalah melalui forum-forum non resmi seperti arisan, genduren, dan sebagainya, serta ketika melakukan komunikasi non formal seperti di warung maupun melalui forum komunikasi yang telah terbentuk. Adanya interaksi sosial dalam masyarakat ini nantinya dapat mempengruhi tingkat kebersamaan yang ada di masyarakat, sehingga juga mempengaruhi sikap dan penanggulangan bencana [8]. Bentuk penilaian risiko bencana secara partisipatif yang pernah dilakukan adalah melakukan penilaian risiko menggunakan software dengan didampingi oleh BPBD, menghitung potensi kerentanan terhadap munculnya bahaya, serta melakukan pemetaan zona bahaya tsunami di lingkungan RW. 08. Selanjutnya adalah perencanaan pengurangan risiko bencana yang pernah dilakukan antara lain merencanakan cara parkir kendaraan yang ada di rumah sehingga memudahkan jika digunakan untuk evakuasi serta merencanakan tindakan evakuasi.

\section{3) Pengorganisasian}

Tabel 4.

Persentase Tahap Pengorganisasian

\begin{tabular}{|c|c|c|}
\hline $\begin{array}{c}\text { Tahapan } \\
\text { Manajemen }\end{array}$ & Tindakan Manajemen & Persentase \\
\hline Pengorganisasian & 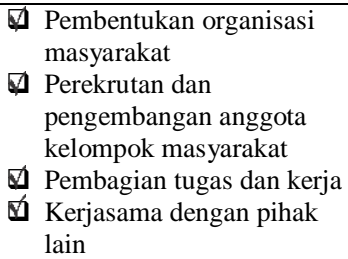 & $100 \%$ \\
\hline
\end{tabular}

Tahap pengorganisasian, masyarakat juga telah melakukan seluruh tindakan manajemen. Bentuk tindakan pembentukan organisasi masyarakat yang dilakukan adalah membentuk kelompok masyarakat sadar keselamatan pantai. Selanjutnya juga dilakukan perekrutan dan pengembangan anggota kelompok masyarakat yaitu berupa rekruitmen anggota secara suka rela dari setiap RT yang ada di RW. 08 dan mengadakan pelatihan-pelatihan untuk mengembangkan keterampilan anggota. Pembagian tugas dan kerja juga dilakukan dalam bentuk pembagian tugas berdasarkan hirarki yang sudah ada serta membago tugas dan kerja berdasarkan kemampuan dan ketrampilan yang dimiliki. Untuk kerjasama dengan pihak lain, masyarakat bekerjasama dengan pemerintah, TNI, POLRI, dan BPBD terkait informasi dan masalah pembekalan kebencanan. Hal ini menumbuhkan adanya sikap untuk menanggulangi bencana, dari mulai adanya pembentukan organisasi masyarakat yang dapat meningkatkan interaksi dan komunikasi, hingga adanya keterlibatan pihak lain yang juga dapat meningkatkan sikap mendorong masyarakat dalam bekerja bersamasama menanggapi risiko tsunami [8].

\section{4) Penggerakan}

Tabel 5.

Persentase Tahap Penggerakan

\begin{tabular}{|c|c|c|}
\hline $\begin{array}{c}\text { Tahapan } \\
\text { Manajemen }\end{array}$ & Tindakan Manajemen & Persentase \\
\hline Penggerakan & $\begin{array}{l}\square \text { Pembuatan sistem peringatan } \\
\text { dini } \\
\square \text { Penyebaran informasi ke } \\
\text { masyarakat } \\
\varpi \text { Peningkatan pengetahuan } \\
\text { masyarakat } \\
\varpi \text { Penggunaan media dalam } \\
\text { penyampaian informasi } \\
\square \text { Pembuatan pusat informasi }\end{array}$ & $80 \%$ \\
\hline
\end{tabular}

Pada tahap penggerakan, masyarakat hampir melakukan seluruh tindakan manajemen hanya pembuatan pusat informasi yang belum dilakukan. Untuk pembuatan sistem peringatan dini, bentuk tindakan yang dilakukan antara lain membuat sistem peringatan dini berupa kentongan dan pos-pos pengawasan, membentuk jaringan informasi melalui HP dan HT, serta memanfaatkan pengeras suara masjid. Penyediaan fasilitas peringatan dini untuk masyarakat merupakan bagian penting untuk mengembangkan kesiapan dalam menghadapi ancaman bencana secara cepat dan tepat [9]. Bentuk tindakan penyebaran informasi ke masyarakat antara lain memanfaatkan forum-forum atau pertemuian rutin, menyebarkan informasi melalui siaran radio komunitas, serta melalui kelompok masyarakat sadar keselamatan. Bentuk tindakan peningkatan pengetahuan masyarakat yang pernah dilakukan adalah bertukar pikiran melalui forum masyarakat, dan mengikuti pelatihan sekaligus berbagi ilmu pengetahuan dari pelatihan yang didapatkan. Peningkatan pengetahuan masyarakat mengarahkan pada terbentuknya pengetahuan lokal (local knowledge) yang menjadi salah satu faktor utama keikutsertaan masyarkat dalam penanggulangan bencana [9]. Selanjutnya untuk penggunaan media dalam penyampaian informasi masyarakat memanfaatkan media elektronik seperti telefon genggam, HT, radio komunitas dan pengeras suara masjid, menggunakan kentongan, serta melalui forum-forum masyarakat. Penggunaan media komunikasi oleh masyarakat dalam menyampaikan informasi juga merupakan salah satu tindakan yang dapat meningkatkan intensitas komunikasi, sehingga mendorong iteraksi sosial yang ada di masyarakat untuk secara bersama-sama menyikapi dan menanggapi bencana [8]. Pembuatan pusat informasi belum pernah dilakukan oleh masyarakat dikarenakan selama ini masyarakat hanya bergantung pada informasi yang diberikan dari BPBD, selain itu jika secara terpusat informasi diserahkan di kantor Kelurahan Ploso.

\section{5) Pengawasan}


Tabel 6. Persentase Tahap Pengawasan

\begin{tabular}{ccc}
\hline \hline $\begin{array}{c}\text { Tahapan } \\
\text { Manajemen }\end{array}$ & Tindakan Manajemen & Persentase \\
\hline \multirow{3}{*}{ Pengawasan } & $\begin{array}{l}\text { ष Pemantauan informasi } \\
\text { Pelaporan informasi }\end{array}$ & $66,7 \%$ \\
& $\square$ Evaluasi partisipatif & \\
\hline \hline & Sumber: Hasil Analisis, 2016
\end{tabular}

Pada tahap pengawasan, masyarakat hanya melakukan 2 dari 3 tindakan manajemen. Bentuk tindakan pemantauan informasi yang dilakukan adalah secara intensif selama 24 jam memantau melalui HT dan memantau informasi yang diberikan oleh BPBD Kabupaten Pacitan. Selanjutnya untuk pelaporan informasi, masyarakat juga telah melakukan meskipun tidak secara formal yaitu melalui media sosial ataupun langsung menggunakan media komunikasi. Sedangkan untuk evaluasi partisipatif belum pernah dilakukan oleh kelompok masyarakat tersebut. Hal ini disebabkan karena kelompok masyarakat sadar bencana masih merupakan kelompok baru, serta masyarakat lebih cenderung hanya terlibat/berpartisipasi dalam tindakan tidak pada evaluasi.

Dari penjabaran diatas dapat diketahui bahwa rata-rata dari tindakan manajemen yang dilakukan oleh masyarakat adalah sebesar $89,34 \%$.

Tabel 7.

Rata-rata Persentase Tahap Manajemen

\begin{tabular}{|c|c|}
\hline Tahap Manajemen & Persentase \\
\hline Manajemen diri & $100 \%$ \\
\hline $\begin{array}{l}\text { Perencanaan dan Pengambilan } \\
\text { keputusan }\end{array}$ & $100 \%$ \\
\hline Pengorganisasian & $100 \%$ \\
\hline 口 Penggerakan & $80 \%$ \\
\hline Dengawasan & $66,7 \%$ \\
\hline Rata-rata & $89,34 \%$ \\
\hline
\end{tabular}

Sumber: Hasil Analisis, 2016

\section{KESIMPULAN}

Berdasarkan hasil analisis dan pembahasan yang telah dilakukan dalam penelitian, maka dapat disimpulkan bahwa:

1) Kemampuan manajemen masyarakat di RW. 08 Kelurahan Ploso sudah sangat baik, ditunjukan oleh rata-rata persentase tahap manajemen mencapai 89,34\%.

2) Tindakan manajemen yang telah dilakukan oleh masyarakat di RW.08 Kelurahan Ploso Kabupaten Pacitan dapat digunakan untuk mengelola (manajemen) risiko bencana tsunami yang berpotensi terjadi lingkungan tersebut, sehingga dengan adanya tindakan manajerial yang dilakukan dapat mengurangi risiko dampak tsunami.

\section{DAFTAR PUSTAKA}

[1] N. National Media Tsunami Guidebook, Silver Spring: NOAA, 2011.

[2] F. Lavigne, R. Paris and P. Wassmer, Learning from a Major Disaster (Banda Aceh, Desember 26th,2004): a Methodology to Calibrate
Simlation Codes for Tsunami Inundation Models, Zeitschrift fur Geomorphologie, 2006.

[3] H. W. Chaeroni and W. Kongko, Pemodelan Tsunami dan Pembuatan Peta Pendaman untuk Keperluan Mitigasi di Teluk Teleng, Pacitan, Yogyakarta: Badan Pengkajian dan Penerapan Teknologi, 2013.

[4] BPBD Kabupaten Pacitan, Dokumen Kajian Risiko Bencana Kabupaten Pacitan Tahum 2014-2018, Pacitan: BPBD Kabupaten Pacitan, 2014.

[5] Y. A. Pradana, Studi Ketahanan Masyarakat Pesisir Pacitan Terhadap Bencana Tsunami, Surabaya: POMITs, 2012.

[6] Sukoco, Meningkatkan Keselamatan Pengunjung Pantai Melalui Pembentukan Kelompok Masyarakat Sadar Keselamatan di Pantai Pacitaan.

[7] K. Krippendorf, Content Analysis: An Introductions to Its Methodology (Second Edition), California: Sage Publication, 2004.

[8] A. Pamungkas, Vulnerability Assessment for Disaster Risk Management: A Case Study of Floods in Centini Village, Indonesia, Melbourne: RMIT University, 2012.

[9] IOC, Reducing and Managing the Risk of Tsunamis, Paris: Intergovermental Oceanographic Commission of UNESCO, 2011. 